\title{
The Role of Education in Upholding the Development of Human Rights Regimes: the Case of the Palestinian Universities
}

\author{
Mohammad Shuibat ${ }^{1, *}$, Mahmoud Abu Samra ${ }^{1} \&$ Nida Shuibat ${ }^{2}$ \\ ${ }^{1}$ Faculty of Educational Sciences, Al Quds University, Jerusalem, Palestine \\ ${ }^{2}$ Hope Flowers Center for Educational and Community Development, Bethlehem, Palestine \\ *Correspondence: Al- Quds University, P.O.20002, East Jerusalem, Palestine. Tel: 972-598-301-457. E-mail: \\ mshuibat@hotmail.com
}

Received: June 21, 2015

Accepted: August 17, $2015 \quad$ Online Published: September 9, 2015

doi:10.5430/wje.v5n5p42

URL: http://dx.doi.org/10.5430/wje.v5n5p42

\begin{abstract}
This paper presents a historical background of the Palestinian education. It outlines a theoretical basis for the development of Human Rights Regimes. The paper tackles the views of some philosophers like Hobbes, Locke, Rousseau and Kant who laid down the foundations for the development of Human Rights Regimes. The paper illustrates that Human Rights grounded in the oldest European civilizations such as in Greek philosophy and in Roman moral and legal thought. Moreover, the paper shows how natural law, social contract, civil constitution and natural rights provide a solid grounding and justification for the development of Human Rights Regimes. After that, the paper tackles the role of education in upholding Human Rights, its approaches, its goals and objectives. The case of the Palestinian universities regarding this matter is also presented.
\end{abstract}

Keywords: human rights; Palestinian universities; empowerment; learning for and about human rights; education

\section{Introduction}

This paper presents a historical background of the Palestinian education. It outlines a theoretical Basis for the Development of Human Rights Regimes. It shows how The American and French Revolutions have led to a dramatic social change in the thinking of many Europeans and Americans at that time. These thinkers like Hobbes, Locke, Rousseau and Kant have led this era which is called the age of reason or/and enlightenment. Furthermore, the paper provides a solid grounding for the development of Human Rights Regimes. These groundings are based on natural law, social contract, civil constitution and natural rights traditions. Then the paper proceeds to illustrate the role of education in upholding Human Rights through the implementation of some approaches like learning about and for Human Rights. The violation of Human rights of the Palestinians by the Israelis is included. The role of the Palestinian universities in resisting these infringements is presented.

\section{Brief Historical Background of Palestinian Education}

The history of Palestinian education is closely linked to the history of the Israeli-Palestinian conflict. During the Israeli- Arab 1948 war, hundreds of thousands of Palestinian Arabs fled to the neighboring countries of Lebanon, Syria, Jordan and beyond, leaving them all as refugees. At that time, the United Nations Relief and Works Agency for Palestine Refugees in the Near East (UNRWA) was established to provide the Palestinian refugees with basic services, including education, which contributed majorly in educating the Palestinians, while people in their neighboring countries were mostly illiterate. Unfortunately, UNRWA schools implemented the educational systems of the host countries. At best, these curricula failed to reflect Palestinian identity and national aspirations; at worst, they deliberately sought to minimize the Palestinian aspirations (Barakat, 2008).

In 1967, the territories known as the West Bank and Gaza Strip came under Israeli military occupation, where existing curricula remained in place, after having been governed by Egypt in the Gaza Strip and Jordan in the West Bank between 1948 and 1967. Since then, Palestinian education under the Israeli occupation was fully controlled and directed by the military administration. Textbooks were heavily censored of any content connected to Palestinian nationalism and identity. In addition, Palestinian education under the Israeli military administration was 
characterized by insufficient supplies and facilities, restricted access to the schools themselves, an inadequate educational budget, an inappropriate curriculum and staffing controlled by security agencies. (Barakat, 2008; Abu-Saad and Champagne, 2006)

In the mid 1970s, the Israeli military administration allowed the emergence of the Palestinian universities for intelligence considerations where it could monitor youth activism. The universities quickly acquired a reputation as centers of Palestinian national achievement, identity and leadership, political struggle and national resistance. After signing the Oslo agreement between the Palestinians and the Israelis, in 1994, the newly created Palestinian Ministries of Education and Higher Education took over educational responsibility from the Israeli military administration as the largest activity delegated to the Palestinian National Authority. The Palestinians finally had the control over the formal educational system which has been controlled by external forces since its establishment. In order to meet their social, economic and cultural needs, the Palestinians had the opportunity to institute reforms to improve the quality of the system. Unfortunately, despite all the attempts made by the Palestinians to improve the quality of their higher education, it is still suffering obstacles set up by the Israeli occupation. The Israeli Occupation denies the Palestinians their basic rights including having security, economic subsistence, and rights to education which we will see later throughout the paper (Barakat, 2008; Abu-Saad and Champagne, 2006).

\subsection{Basis for the Development of Human Rights Regimes}

The American and French Revolutions led to a dramatic social change in the thinking of many Europeans and Americans at that time (Hayden, 2001). These critical events in the history of the Western world have resulted in the creation of democratic regimes founded on the rights of man, rather than the divine right of kings. In fact, the idea of reason has shaped thinking, in the modern ages about the issue of rights. The early modern era is often referred to as the age of reason or enlightenment. Several philosophers have led this era like Hobbes who was probably the writer who was most responsible for the inauguration of modern social and political philosophy. Hobbes' philosophy was based on the supreme authority of the sovereign who derives power from the natural rights of the people based on the social contract. Natural law is the basis of Hobbe's social contract in that the source of natural law is the right to life and liberty of each person, who then agree to transfer his or her right of liberty to a sovereign to maintain security through the contract (Hayden, 2001).

Other philosophers like Locke, Rousseau and Kant modified and extended the social contract theory. An important modification of Hobbes' ideas of the social contract came from Locke who regarded the transfer of rights by the people to the sovereign as partial, not absolute, as Hobbes mentioned. This expanded the natural rights which were recognized in social contract theory and helped establish the notion of the supremacy of the people in limiting the authority of the government. People give their consent to obey the sovereign only insofar as their individual rights are guaranteed, according to Locke, and in the event that the government violates their rights, the people are released from obedient ties to the government and may rightfully overthrow that government. The approach that Rousseau made to the idea of a social contract was in a way much more profound than that of Locke's. The social contract, for Rousseau, was between all members of society, and it became the basis for human claims, rather than "natural" rights. We can live together without succumbing to the force and coercion of others, Rousseau maintained, by submitting our individual wills to the collective will, created through an agreement with other free persons, with whom we are equal. Rousseau asserted that no one has a natural right to govern others because of his belief that all men are made by nature to be equal and therefore the only just authority is one that is generated out of the social contract, as no one has a natural right to govern others (Hayden, 2001; The Internet Encyclopedia of Philosophy, 2006).

In congruence with Rousseau, Kant discusses the civil state and how it is based on a social contract. The conception of a social contract emphasizes the notion that humanity should be an end in itself, rather than a means toward an end. In a just civil state a correlative duty is established toward each right, that is, every human has a duty to protect or respect the rights of other human beings. This obligation toward other humans sanctions the rights of man. Thus in the civil state, humans are not one hundred percent free. Through the rule of law and the state rights to punish those who go against the rule of law, freedom of the citizenship is somewhat minimized. But these limitations are legitimate since they actually increase freedom by prohibiting the types of wrongs that are characteristic of the lawless state of nature. For Kant, the civil state is highly valued, as it protects and provides us with our natural rights to freedom and grants us the bases to acquire our other rights. Another important point in the development of the civil state is the establishment of the civil constitution. This constitution is looked at as a compact by which a number of humans are united to form a society. This union among people helps them to promote the shared ends, which they hold, for the sake of their well being (Hayden, 2001).

What influenced the modern age's emphasis on reason was the ethical tradition of natural law that is natural law 
tradition has provided a solid grounding for natural rights and thus Human rights (HRs). This relationship between natural law, natural rights and HRs is the focus of this section. Natural law doctrine is grounded in the oldest European civilizations such as in Greek philosophy and in Roman moral and legal thought. Natural law theory posits that through the use of reason, human beings are able to act in accordance with the values of natural law and thus bring about the moral and political order, which are required for the common good. As human beings are endowed with the right conduct and common good by nature, natural law philosophy provides a solid grounding and justification for the contemporary HRs tradition (Hayden, 2001; Maritain, 1945).

Hayden (2001) stated that natural law proponents argued that humans are able to distinguish right from wrong naturally and have the capacity to deduce rules of moral conduct, which are in conjunction with the universal nature of right or wrong. Although the thinkers of natural law did not have a clear idea of what HRs look like, they laid down the foundations for thinking about the essence of being a human who seeks for justice, as a moral good. Thus, natural law theory helped in promoting our thinking about HRs by associating rationality with the idea that each person possesses rights and obligations simply by being human. The idea of reason and its implications on the thinking of many philosophers of what proper conduct is became the solid ground on which philosophers built the concept of natural rights (Finnis, 1980; Hayden, 2001; Maritain, 2001).

However, one can argue that these rights and obligations can be derived from natural law. Finnis (1980) posits that a group of basic practical principles can be identified which indicate the basic forms of human flourishing as goods to be pursued and realized. These principles identify human ends and the means to them. Practical reasonableness provides the criteria for distinguishing between acts that are reasonable for one to follow and acts that are unreasonable for one not to follow. Practical reasonableness directs us to differentiate between ways of acting that are morally right or morally wrong. It enables one to formulate a set of general moral standards, that every human is an end, not a means toward an end. The notion of 'do good and avoid evil' is where the natural law derived its principles. These principles require that authority be exercised in a manner, which is consistent with the Rule of Law, and with due respect for the HRs which exemplifies the requirements of justice (Elgarrai, 2000; Finnis, 1980).

Vincent (1986) asserted the principle that HRs have been said to express the requirements of practical reasonableness. These principles make possible the achievement of the end of human flourishing by connecting together nature and reason. The basic goods are life, knowledge, play, aesthetic experience, sociability, and religion. The knowledge of basic good in itself is self-evident, as it is known by inclination and connaturality, not through conceptual knowledge or by way of reasoning. Principles of practical reasonableness guide us to promote a common good in which such respect for rights is a component. What is essential to the common good is justice and moral righteousness. That is why the common good requires the development of the virtues in citizens, and that is why every unjust and immoral political act is to be considered damaging to the common good and the political system.

Hayden (2001) explained that natural rights theory proposes that there are some essential characteristics common to all humans, such as rationality and the grounding of certain inherent rights in human nature. A core principle of natural rights theory is that we have some fundamental rights, simply by being humans. Because all humans share the same humanity, the rights we enjoy and exercise are also universal. These rights existed independently and prior to any political society. Natural rights are inalienable, meaning that they cannot be confirmed or taken away by a society. This notion is congruent with the proposition that the purpose of the government should be to protect the natural rights of its citizens. When government adheres to the principle of serving its subjects, those subjects will enjoy equality and freedom, which are considered two essential features of a good life and human flourishing. According to natural rights theory, all humans are in a way equal, simply, because they possess the same basic rights. We see this equality has been asserted in different documents like the French Declaration of the Rights of Man and of Citizen, which states, "All men are by nature free and equal in respect of their rights" (Hayden, 2001, p. 21).

Hayden (2001) explained that the conception of equality among all humans, according to natural rights theory, lead to how humans should be treated. For this reason, natural rights are often thought as moral claims or entitlement that exists independent from any legal system. In general, freedom or liberty is a vehicle to the idea that all people are equal and entitled to basic rights. When people are free, they can exercise self-determination and there will be no coercive constraint on their actions. Freedom is closely connected to natural rights because those rights cannot be realized if our conduct is so constrained or obstructed that we are unable to act in order to pursue their fulfillment. Ultimately, Kant declares, "Civil society should protect each person's equal right to freedom, which is to be exercised under the influence of rationality and, therefore, in agreement with the duties of justice and morality" (Hayden, 2001, p.176).

Maritain (1945) laid down the foundation for the relationship between natural rights and HRs, being that natural 
rights are derived from natural law. Natural law is not a written law; it is structured in reason and human consciousness. Thus HRs are derived from natural rights as they are linked to the very nature of being human. Human beings possess rights because; humans by their nature are masters of themselves and of their acts, and consequently are not merely a means to an end, but an end in itself. The dignity of the human being must be respected, according to natural law. The respect of human dignity is the subject of rights. Maritain (1945) illustrated that HRs are grounded in natural rights as follows:

The notion of right and the notion of moral obligation are correlative. They are both founded on the freedom proper to spiritual agents. There are things, which are owed to human beings because of the very fact that they are humans. If man is morally bound to the things which are necessary to the fulfillment of his destiny by nature, obviously, then, he has the right to fulfill his destiny; and if he has the right to fulfill his destiny he has the right to the things necessary for this purpose (p. 65).

What can be deduced from this illustration is that HRs are grounded in natural law, social contract, civil constitution, natural rights, and the oldest European civilizations such as in Greek philosophy and in Roman moral and legal thought. As it is well-known these days, the development of HRs regimes came in a wake of series of events that terrified the world. These events led the UN to adopt the Universal Declaration of Human Rights (UDHR) in 1948 as a legal document for all nations to abide by. At the same time, the UN called upon Governments to have the responsibility not only for providing their citizens with education concerning HRs, but also they are responsible to guarantee their citizens the social, political, economic, negative, positive and basic rights. (Elgarrai, 2000).

What has been mentioned concerning the development and awareness of Human Rights can be gained through a more comprehensive Human Rights Education (HRE) than what is in place now. The following section tackles the issue of the necessity for HRE, its approaches, its goals, its objectives and a brief outlook at HRE at Palestinian universities. The central role which these universities played in resisting the infringements of the Israeli occupation against the Palestinian rights is detailed.

\section{Human Rights Education}

Over the last two decades, numerous entities have become concerned with HRE, among them are ministries of education, non-profit organizations, HRs advocacy groups and teachers. Additionally, inter-governmental agencies such as the UN and regional agencies have expressed interest in HRE. The terms democracy, peace, and HRs altogether form a shield to strengthen respect for HRs and fundamental freedoms and to ensure such respect in all societies. Therefore, human rights are not only for evaluating and respecting but are also about advocacy to guarantee these conditions. In so-called developing countries, HRE is often connected to the economic and social developments such as women's rights, while in the authoritarian countries; HRE is mainly associated with the development of the infrastructure of the society and the protection of minorities and individual rights. This has been seen in the historical struggle against the political authority in the French Revolution, when the people proclaimed individual rights and the sovereignty of the nation, while the government was manifesting its hostility towards minorities and the partial associations between groups of people (Freeman \& Beetham, 1995; Tibbitts, 2002).

The democratic and egalitarian illustrations of HRE issues propose critical questions about the complex role of education in supporting social change and human development. All groups who are advocates of HRE conduct trainings, develop materials, and design programs to implement change strategies. In this section, the authors assert that HRs groups should be ready to re-examine their practice so that the field can be further professionalized and linked with effective change strategies because HRE, by its nature, should be helpful in transcending national, social, cultural, economic and other boundaries. When the UDHR was announced in 1948 by the UN, it had 30 paragraphs, which can be used as the basis for any curricula of HRE. These amendments included fundamental rights and freedoms as well as the moral values, which support them. (Lohrensheit, 2002). The UDHR has laid the foundations of the right to education as well as HRE in particular, as it was stated by Hufner (1998):

Everyone has the right to education.... education shall be directed to the full development of human personality and the strengthening of respect for human rights and fundamental freedoms. It shall promote understanding, tolerance and friendship among all nations, racial or religious groups, and shall further the activities of the United Nations for the maintenance of peace. (p. 175).

Human rights education is supported by the idea that a human being has rights merely because he/she is human; human rights education is aimed to protect and promote the rights of every human being. In the real world, education 
for human rights is often translated into or depends heavily on education for citizenship. If the purpose of human rights education is to cultivate the idea that all human beings are born equal and free in dignity and rights, therefore every human being's rights need to be protected and improved. A basic understanding of human rights education should be 'human beings are human without condition.' All human beings should have rights merely because they are born members of Homo sapiens, rather than being justified by any form of membership. In this respect, every human being is entitled to his/her rights regardless of his/her membership of a group, community or a country. That every human being is equal to each other is based on a simple fact: everyone is a living body (Hung, 2012). The overall goal of any HRE should be to promote the raising of consciousness and an active respect for HRs as formulated in the UDHR. Therefore, HRE should become an integral part of the mainstream of education and be integrated into all subjects in general and in civics education, in particular (Hornberg, 2002; Lenhart \& Savolainen, 2002; Tibbitts, 2002; McCowan, 2012, 2011; Cassidy et al, 2013).

If we apply these notions of rights and HRE with all their emphasis on respecting human dignity, freedom and flourishing, to the context of Palestinian university students, we find that Israel has subjected the students as well as the universities to the extent that Israel has the ability to interfere with their operation by controlling the movement of Palestinians and has subjected these institutions to its full control and by blocking expansion of and resources to the universities. Israel, as we will see later, by its oppressive acts has denied the Palestinian university students their rights to education as well as their rights to self determination and to become an integral part of the world community. Despite these violations by Israel, the universities remained to play a critical role in resisting these infringements and empowering the Palestinian students (Bruhn, 2006). The upcoming sections cover the issues of learning about and for HRs, HRE and empowerment.

\subsection{Learning about Human Rights: Learning for Human Rights}

For the last two decades, learning about and for HRs has received much attention. Materials, documents, booklets, and class pamphlets have been published to support this intention. Many of these materials can be downloaded freely from the Internet, in order for the public to get the full benefit from them. Different groups such as children, women, and minorities have been targeted so that they can better understand their rights and defend them. Human rights education can be based on two distinctive principles: learning about and learning for HRs. The first principle, learning about HRs, consists of the knowledge of the generations through history, documents, and the relevance of the established instruments for the realization of HRs. Learning about HRs requires those who are involved in the process to know the different aspects and the controversies of the topic. As it has been pointed out, this approach demands the understanding of the basics of the UDHR. The accumulation of knowledge and the understanding of the value of HRs are emphasized. The understanding of the HRS and HRE by the Palestinian University students demonstrates the capacity of these universities to empower the Palestinians as they confront the Israeli challenge to their identity and their profound connection to their homeland. See Anzaldua (1987) book Borderlands La Frontera in which she called herself someone never comfortable with the American culture but who was instead keenly bonded to her identity as Indian, Mexican, Espanyola, Chicana, Tejana, and mestiza. The case of Palestinian universities ensures the potential of these universities to empower communities to engage in a process of social and political change. The emergence of Palestinian universities during the beginning of the seventies of the last century have provided Palestinians with a medium for self-expression that has empowered Palestinian communities to confront the challenges they faced during the long Israeli occupation. The high capacity of Palestinian universities to empower Palestinian communities to confront the Israeli occupation challenges provides an excellent example of the potential impact of the universities on social and political change. Increased access between the Palestinian universities and the Palestinian students resulted in greater inclusion of Palestinian communities in the activities of the universities, transforming them into dynamic social forces that paved the way for the articulation of a Palestinian national consciousness, facilitated resistance to the Israeli occupation of Palestine, and fostered the preparations for a Palestinian state. To what extent Palestinian universities will continue to empower Palestinian communities depends largely on the capacity of the universities to safeguard Palestinian self-expression and educating Palestinian university students through these institutions (Bruhn, 2006; Lohrensheit, 2002; Sliwinsky, 2005; Ty, 2011).

Human rights education then proceeds to the second principle, which is learning for HRs. Here is where the empowered and the dynamic individual is the target of HRE. The individual is required to understand power structure in order to be able to realize his/her own needs and the cause and effects of the social structure in which he/she lives, or the world as a whole. Moreover, the acquisition of emancipatory concepts, such as those that are contained in Freire's (1970) Pedagogy of the Oppressed, demandable by the individual. This common understanding by the free and empowered individuals of HRE implies the transformation of the whole society, socially and economically, on the basis of HRs. Israeli actions which involve administrative detention without charge or trial, 
torture of and forced confessions from detainees show the harsh conditions in which the Palestinians are living. Other violations of civil and human rights by the Israelis against the Palestinians include the shooting and beating of unarmed individuals, deportation without specific charges, the suppression of Palestinian voices (e.g., the use of the word 'Palestine', and display of the Palestinian flag, are all crimes punishable by jail), curfews, intimidation of families of individuals whose members are jailed, military censorship of all publications, confiscation of land and water resources, and the continuing construction of the separation wall and new settlements look like the apartheid South Africa, with Palestinians on one side and Israelis on the other. Furthermore, there are roads that only Israelis can use and Palestinians can not. This makes life almost impossible for Palestinian families, students and academics. Arrests, violence, detention and death against the Palestinian university students are contrary to academic freedom and the basic right to education. Despite of all that violence by the Israelis, academic culture still flourishes at the Palestinian universities (Hammond, 2007).

Lohrensheit (2002) and Ty (2011) assert that education for HRs emphasizes social competencies such as solidarity and collective action for the well being of the society as a whole. The understanding of HRE requires a deep understanding of the tension between the two principles of for and about, or an adaptation/combination of the two. An adaptation/combination of the two principles implies a critical analysis and understanding of the status quo of the society. With this understanding, humans can define their needs. When the individual finds out that his/her needs are not fulfilled, he/she resists in order to satisfy personal, as well as others', needs. Because of these reasons, Palestinian universities have become centers of resistance against the Israeli occupation (Hammond, 2007). When Palestinian university students see their rights are infringed on a daily basis, they question the true meaning and function of all HRs documents and working agencies in the field. Thus, it is becoming too difficult to convince the students with the values of rights particularly when students see how the Israeli occupation gains support from the west in general and the USA in particular despite all the violations the occupation commits in the Palestinian land.

The comprehensive understanding of HRE entails the learning environment and the existing structures or hierarchies in the organizational framework make participatory learning possible. Learning through participation, democratic structures or negotiation and conflict resolution can nurture HRE. In order for teachers to increase the capacity of their learners, they need to examine the existing educational structures as well as the curricula. If there is an insistence on inflexible curricula and rigid educational structure, it will hinder the creativity of learners and by doing that, students might be led to violate or misuse the power and democratic means, in order to attain their rights (Lohrensheit, 2002).

Nevertheless, the definition of HRE principles leads to the development of curricula competencies, which are necessary in HRE processes. Lohrensheit (2002) explains the basics of HRE as defined by Norma Bernstein Tarrow, as follows:

From the global perspective, a common core of human rights education includes four basic elements: (1) Knowledge of the main international human rights documents; (2) The combination of human rights and human duties that emerge out of them as well as the responsibility of the individual towards the community, society and the developing 'world society'; (3) Knowledge about human rights violations (including all forms of inequality and discrimination); (4) The various forms of resistance, key events and important persons or organizations within the world-wide struggle for human rights. (p. 178)

If any observer look at the Israeli actions of humiliating the Palestinian university students at the roadblocks he or she can deduce that these violations are violations of every academic freedom that have ever been held sacred in the civilized world. Israel has openly flaunted the United Nations Universal Declaration of Human Rights, the 1960 UNESCO Convention against Discrimination in Education, the four Geneva Conventions of 1949 and a catalogue of other human rights covenants. Violations aim to make it impossible for intellectual elite to develop; that is capable of arguing the case for Palestinian rights, autonomy and the right to return to their 1948 homeland. The Israeli army, however, have not been successful in squashing higher education and Palestinian culture. In even more oppressive conditions, the universities have become centers of resistance. Palestinians have learned that to simply keep going in the conditions of occupation is to keep possibilities alive for a more humane future (Hammond, 2007).

\subsection{Human Rights Education and Empowerment}

Human Rights Education (HRE) is defined as a set of educational and pedagogical learning methods to inform people of and to train them about their human rights. HRE aims to provide information about the international or regional human rights norms, standards, and systems and to provide people with the skills and change their attitudes that lead to the protection and support of human rights. Educating people in their human rights should empower them to know and use their human rights to protect themselves and others from human rights violations (Mihr, 2009). 
Human rights education could help to bring about the human action necessary in creating a more just and peaceful world, if it is prioritized over the world. Meintjes (1997) presented that the idea of HRE as empowerment could be approached from two different perspectives. First, one could adopt a general and abstract approach and focus upon the fact that the UDHR is a common standard of achievement for all people and all nations. By teaching and educating, every individual shall endeavor to promote respect for HRs and freedoms and to secure their universal and effective recognition and observance by using progressive measures, both national and international. Second, one could adopt a more concrete approach and focus on the values and experiences that can be demonstrated by HRE. For example, a person can participate in peace keeping missions and monitoring election campaigns, which are sponsored by the UN to maintain peace and order in different parts of the world. Today, as HRE is thought of as empowerment, these two approaches should be kept in mind. Real empowerment can only occur if the knowledge and experiences to be gained through HRE are integrated (ElGarrai, 2000).

The question that can be raised here, can we as Palestinian university professors use the concept of HRs empowerment to empower Palestinian university students? The answer is that as long as the Israeli occupation dominates our life we will not be successful to achieve this goal. The objectives of HRE as empowerment are different from any objectives of any conventional discipline. Human rights education as empowerment at the grassroots level is often viewed as threatening and antagonistic to some forms of elite government institutions. Meintjes (1997) defined empowerment as "a process through which people and/or communities increase their control or mastery of their own lives and the decisions that affect their lives" (p. 165). Paulo Freire (1970) in his term "Banking Model of Education," suggested that to treat students simply as receptacles to be filled and deposited with useful ideas and information is to deprive them of their critical consciousness and to deceive them into believing that knowledge is an object to be received rather than a continuous process of inquiry and reflection. Students who are empowered become aware of their abilities to create knowledge and to conceptualize and reconceptualize their experiences of reality. Therefore, HRE, as empowerment, demands that each target group be able to begin the process of acquiring the knowledge and critical awareness they need to understand and question oppressive patterns of social, political, and economic organization. The end goal of this process is liberating and its success depends on the abilities of those empowered to transcend the previously oppressive power relations. This will require from those who are empowered to be equipped with the abilities to envision, develop, and function within new non-dominating patterns of organization in which the human dignity of everyone is protected and promoted. In order for the Palestinian universities to play their role as a forum for critical thinking, technical expertise, and community leadership, they have to be fully liberated from the Israeli occupation because there is close relationship between academic freedom, human rights, and the right to self-determination (Nasir, 1993).

Empowerment should not target certain individuals, groups, or ethnicities, but it should be directed to all marginalized or alienated individuals, groups or ethnicities in all societies and at all times. The goals of HRE as empowerment could be outlined in the context of understanding the various international HRs instruments in their national and global discourse. In this view, empowerment should encourage tolerance among people and it should help them to adhere to the principles of respect of human dignity by positing on the principle of equality among all human beings. The goals of HRE as empowerment should increase the knowledge of some of the infringements, violations of and discriminations against some HRs. The distinction between political, legal and socio-economic rights is also included. What is also important is the development of sympathy and empathy to those whose rights are denied, as both are the rudiments of morality. The goals mentioned above are considered to include both cognitive and attitudinal objectives. Human rights education, as empowerment, should include behavioral change objectives such as learning tolerance toward refugees and the promotion of attitudes of solidarity. A typical example is an African-American Studies program that engenders concern and respect for the people of Africa and their problems related to food distribution, health, and the welfare of refugees. The utmost goal of education as empowerment should be to enable people to define and meet their needs (Meintjes, 1997; Ty, 2011).

The design of empowerment pedagogies should always be significant to the learner. It should be authentic and reflect real life situations. It should not be unreal and static in nature for several reasons. First, human rights are inherently about relationships. They are concerned with the power relations between individuals, groups, society, and/or the state. They are inevitably always dynamic and relative, that is, they have social and political functions, which cannot be ignored. In other words, students' social and political choices can be enhanced by teaching them the concepts and values embodied in HRs. Second, there are no limits to the range of relations that might affect HRs. Therefore, any attempt aiming at establishing boundaries between HRs and other areas of human knowledge is likely to be illogical and ill defined. Third, it is important that HRE be contextual in nature, that is, focus upon the specific experiences, needs, and problems of its participants as it is their relationships with each other, their community, their 
environment, and their government that must be transformed or enhanced (Meintjes, 1997).

In summary, we can deduce that the natural law tradition provides a solid grounding for natural rights and thus HRs. Natural law also explicates that the formation of the social contract is contingent upon the apprehension of the use of reason in discerning what is good and right, which is expressed most powerfully in the natural law tradition. One of the chief purposes of morality and the conception of basic HRs is to provide some minimal protection against utter helplessness to those too weak to protect themselves. This can be achieved through Human rights Education which aims to promote and protect human rights through 'imparting of knowledge and the molding of attitudes. Moreover, this protective role of HRs and HRE has to be seen within the context of the Palestinian university students, otherwise they will continue to suffer the infringements of the Israeli occupation to the land of Palestine (Hayden, 2001; Maritain, 1945, 2001; Stanford Encyclopedia of Philosophy, 2000).

The question that can be raised here, are we still living in the time when man must fight and die in order to have the right to be a full citizen of a nation? This question is relevant to the Palestinians in their home land; belonging to the nation has been connected to creating meaning around perceived injustices and hardships they encounter as they go about their daily life under occupation. Palestinians are reminded daily at checkpoints and border crossings in the occupied territories, that their identity as Palestinians is the source of their disempowerment and lack of basic rights, including the right to freedom of movement, to access jobs and other daily survival activities. Therefore, HRE should be a huge task for the Palestinian universities to implement and train their students on, so as they understand that they have rights to live in peace and security as well as any nation and those who occupy their land and violate their rights will realize their immoral doing sooner or later (Hovsepian, 2011).

\section{References}

Abu-Saad, I., \& Champagne, D. (2006). Introduction: A Historical Context of Palestinian Arab Education. American Behavioral Scientist, 49(8), 1035-1051. http://dx.doi.org/10.1177/0002764205284717

Anzaldua, G. (1987). Borderlands- La Frontera, The New Mestiza. USA: Spinsters/ Aunt Lute.

Barakat, B. (2008). Education and Intra-alliance Conflict: contrasting and comparing popular struggles in apartheid South Africa and Palestine. Research in Comparative and International Education, 3(1), 5-18. http://dx.doi.org/10.2304/rcie.2008.3.1.5

Bruhn, C. (2006). Higher Education as Empowerment: The Case of Palestinian Universities. American Behavioral Scientist, 49(8), 1125-1142. http://dx.doi.org/10.1177/0002764205284722

Cassidy, C., Brunner, R., \& Webster, E. (2013). Teaching human rights? 'All hell will break loose!'. Education, Citizenship and Social Justice, 9(1), 19-33. http://dx.doi.org/10.1177/1746197913475768

ElGarrai, O. A. (2000). Problems and prospects of human rights education in Arab Islamic region: Egypt as a case study, PhD Thesis, University of Ohio, Columbus.

Finnis, J. (1980). Natural law and natural rights. Oxford UK: Clarendon Press.

Freeman, M., \& Beetham, D. (1995). Are there collective human rights?, Political Studies, 43(4), 25-41. http://dx.doi.org/10.1111/j.1467-9248.1995.tb01734.x

Freire, P. (1970). Pedagogy of the oppressed. New York: The Continuum Publishing Company.

Hammond, K. (2007). Palestinian Universities and the Israeli Occupation. Policy Futures in Education, 5(2), 246-270. http://dx.doi.org/10.2304/pfie.2007.5.2.264

Hayden, P. (2001). The philosophy of human rights ( $2^{\text {nd }}$ ed.). St. Paul MN: Paragon House.

Hornberg, S. (2002). Human rights education as an integral part of general education, International Review of Education, 48, 187-198. http://dx.doi.org/10.1023/A:1020330131832

Hovsepian, M. (2011). Desecularization of the Palestinian Imagination? Reflections on Nation-Ness and

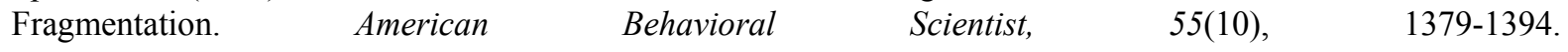
http://dx.doi.org/10.1177/0002764211411174

Hufner, K. (1998). How to file complaints on human rights violations. International Review of Education, 44(2-3), 155-175.

Hung, R. (2012). Being human or being a citizen? Rethinking human rights and citizenship education in the light of Agamben and Merleau-Ponty. Cambridge Journal of Education, 42(1), 37-51. 
http://dx.doi.org/10.1080/0305764X.2011.651202

Lenhart, V., \& Savolainen, K. (2002). Human rights education as a field of practice and of theoretical reflection. International Review of Education, 48(3-4), 145-158. http://dx.doi.org/10.1023/A:1020382115902

Lohrenscheit, C. (2002). International approaches in human rights education. International Review of Education, 48(3-4), 173-185. http://dx.doi.org/10.1023/A:1020386216811

Maritain, J. (1945). The rights of man and natural law. New York: Charles Scribner's Sons.

Maritain, J. (2001). Natural law: Reflections on theory and practice. South Bend IN: St. Augustine's Press.

McCowan, T. (2011). Human rights, capabilities and the normative basis of "Education for All". Theory and Research in Education, 9(3), 283-298. http://dx.doi.org/10.1177/1477878511419566

McCowan, T. (2012). Human rights within education: assessing the justifications. Cambridge Journal of Education, 42(1), 67-81. http://dx.doi.org/10.1080/0305764X.2011.651204

Meintjes, G. (1997). Human rights education as empowerment: Reflections on pedagogy. In Andreopoulos, G. J. \& Claude R P (Eds.), Human rights education for the twenty-first century. Philadelphia, PA: University of Pennsylvania Press.

Mihr, A. (2009). Global human rights awareness, education and democratization. Journal of Human Rights, 8, 177-189. http://dx.doi.org/10.1080/14754830902939080

Sliwinski, S. (2005). Thinking without banisters: towards a compassionate inquiry into human rights education. Educational Theory, 55(2), 219-230. http://dx.doi.org/10.1111/j.0013-2004.2005.00008.x

Stanford Encyclopedia of Philosophy, (2000). Contractarianism. Retrieved from http://plato.stanford.edu/entries/contractarianism/

The Internet Encyclopedia of Philosophy. (2006). Social Contract Theory. Retrieved from http://www.iep.utm.edu/s/soc-cont.htm\#SH2c

Tibbitts, F. (2002). Understanding what we do: Emerging models for human rights education. International Review of Education, 48(3-4), 159-171. http://dx.doi.org/10.1023/A:1020338300881

Ty, R. (2011). Social injustice, human rights- based education and citizens' direct action to promote social transformation in the Philippines. Education, Citizenship and Social Justice, 6(3), 205-221. http://dx.doi.org/10.1177/1746197911417413

Vincent, R. (1986). Human rights and international relations. Cambridge MA: Cambridge. 